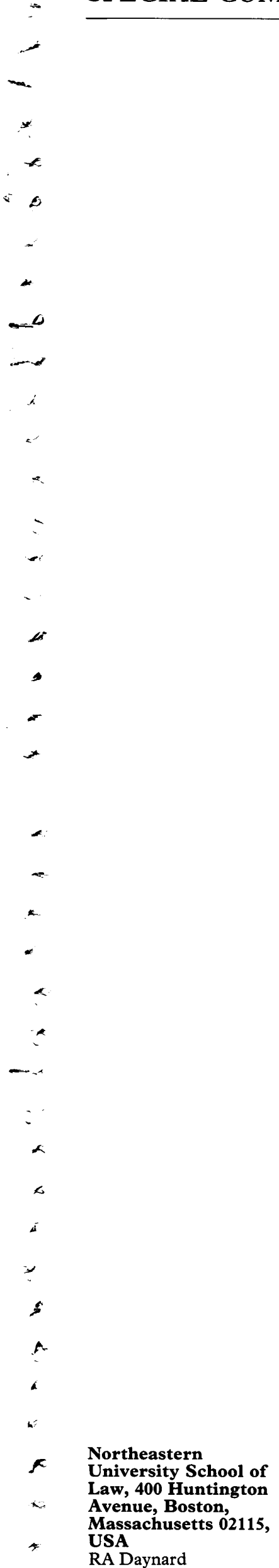

\title{
Catastrophe theory and tobacco litigation
}

\author{
Richard A Daynard
}

\begin{abstract}
While the tobacco industry has thus far been successful in fending off product liability suits, thereby reducing litigation activity against it, a possible industry defeat in any of six legal areas would be likely to produce dramatic increases in anti-tobacco litigation. Public outrage at accumulating evidence of industry fraud and conspiracy increases the probability of civil or even criminal liability. "Public interest" actions may permit courts to enjoin unfair and deceptive marketing techniques. Recent judicial decisions have simplified the process of winning tobacco products liability suits. Thirdparty victims, whether of cigarettecaused fires or of environmental tobacco smoke, make especially appealing plaintiffs. Smokers are beginning to seek reimbursement for their expenses in breaking their nicotine addiction, while insurance companies and uncompensated health care providers may begin suing cigarette manufacturers for their fair share of health care expenses.
\end{abstract}

(Tobacco Control 1994; 3: 59-64)

Since the first review of tobacco litigation appeared in Tobacco Control two years ago, ${ }^{1}$ there have been promising developments but no breakthroughs. Advocates have been accused of "crying wolf", with sceptics arguing that predictions are better made by extrapolating from the industry's proud record of never having paid a penny to its victims than by analysing potentially favourable developments which have yet to produce a payout. ${ }^{2}$

There is a limited but important class of tobacco cases where the plaintiffs have won... but not against the tobacco industry. In cases involving employees who have been injured by environmental tobacco smoke (ETS) on the job, employers have been required to pay substantial damages. Thus, for example, in 1992 an Australian psychologist recovered $\$ 85000$ from her employer, the Department of Health, for having exposed her to ETS from 1974 to 1984, thereby causing her emphysema and aggravating her asthma. The evidence suggested that the Health Department should have known from the late 1970s about the dangers of ETS, and was therefore both negligent and in violation of laws protecting employees from "vitiated" air and "injurious or offensive" fumes. ${ }^{3}$ In 1993, an employee in the Honolulu city attorney's office recovered disability compensation benefits for her adenocarcinoma of the lung; the Director of Hawaii's Disability Compensation Division accepted her evidence that her cancer was caused, at least in part, by her 28 years of workplace exposure to ETS. ${ }^{4}$

The sceptics' main claim, however, that the tobacco industry itself is untouched and thus presumably untouchable, remains to be confronted.

The first thing to notice is how hard the industry has worked to maintain its "wenever-paid-a-dollar" status. Michael Pertschuk, co-Director of the Advocacy Institute, has estimated that the industry spends $\$ 600$ million per year defending the 50 or so cases pending against it. ${ }^{5}$ Time Magazine estimated that the industry spent at least $\$ 75$ million defending the Cipollone case alone. ${ }^{6}$ Indeed, an RJ Reynolds attorney made the strategy explicit in an internal memorandum: "the way we won these cases was not by spending all of Reynolds' money, but by making that other son of a bitch spend all of his". "Spending far more to defeat each case than would be required to settle the case would make no economic sense, however, if the stakes were limited to that one case. Rather, what the industry fears - and must fear - is not writing checks to a few plaintiffs, but the public collapse of its reputation as being invulnerable to legal claims.

The industry's predicament can be explained through "catastrophe theory". "A mathematical model for dealing with discontinuous and divergent phenomena," 8 catastrophe theory applies to situations characterised by bimodality, radical instability at the point of transition, acute sensitivity to slight changes in the initial conditions in determining which of the two possible modes is initially assumed, hysteresis (a stickiness to the current mode of behaviour, delaying the transition), and sudden changes from one mode of behaviour to another. Where catastrophe theory applies, extrapolation from past conditions is extremely hazardous.

Like asbestos litigation, ${ }^{9}$ tobacco litigation is probably bimodal. In the current situation, with fewer than 100 cases pending, only especially brave or committed attorneys attempt to take on the cigarette companies, who are playing "king of the mountain", outspending each attorney who dares attack them. We can imagine a situation in which plaintiffs' attorneys are no longer frightened of the industry: there would then be tens of thousands of cases, reflecting the tremendous toll that cigarettes take. ${ }^{10}$ It is hard to imagine an 
intermediate, relatively stable situation, cases flowing successfully through the legal system, just a few at a time. Rather, the situation would be likely to be radically unstable at the point of transition, since many lawyers would jump in once their expected returns began to exceed anticipated costs.

Furthermore, had the first wave of tobacco litigation prevailed, as it came close to doing, ${ }^{11}$ we would now be in a situation in which the tobacco industry's victims would ordinarily bring suit (assuming intervening political developments had not transformed the situation entirely). Thus, the current, low-litigation mode is the result of the earlier situation, which could easily have been different. The current situation is obviously sticky, since a plaintiff's attorney will have to be unusually lucky, skillful, or well financed to beat the industry, and thereby transform the situation to the high-litigation mode. Finally, since any plaintiff's "breakthrough" will surely be widely and prominently reported, the transition between modes would be likely to occur very quickly.

Since we are now in the low-litigation mode, the question remains whether anything is happening that could produce a catastrophic tobacco industry loss. In fact, there are currently six developing areas of tobacco litigation, any one of which could produce such a catastrophe.

\section{Fraud and conspiracy}

The US Supreme Court's 1992 decision in Cipollone v Liggett Group, Inc, made clear that claims that the cigarette companies engaged in intentional fraud or misrepresentation, whether by false representation of a material fact or by concealment of a material fact, are not pre-empted. It also held that claims alleging a conspiracy "to misrepresent or conceal materials facts concerning the health hazards of smoking" were not pre-empted; indeed, in a footnote it quoted District Judge Sarokin's description of the evidence of conspiracy:

"Evidence presented by [petitioner], particularly that contained in the documents of [respondents] themselves, indicates...that the industry of which these [respondents] were and are a part entered into a sophisticated conspiracy. The conspiracy was organized to refute, undermine, and neutralize information coming from the scientific and medical community..."12

The documents Judge Sarokin saw in the Cipollone case may just have been the tip of the iceberg, in terms of potentially incriminating material in tobacco industry files. In Haines $v$ Liggett Group, Inc, ${ }^{13}$ Judge Sarokin reviewed an additional trove of documents, these drawn from the Council for Tobacco Research's "special projects" division. He found support in these documents for finding that "the industry research which might indict smoking as a cause of illness was diverted to secret research projects and that the publicized efforts were primarily directed at finding causes other than smoking for the illnesses being attributed to it." He concluded that these documents were not protected by the attorney-client privilege, as the industry had claimed, because the industry's attorneys had been participating in an on-going fraud (the "crime/fraud" exception). While his pithy summary of the situation, that "despite some rising pretenders, the tobacco industry may be the king of concealment and disinformation," led an appellate court to disqualify Judge Sarokin from further consideration of the case on grounds of "an appearance of partiality," the court agreed that the evidence cited by Judge Sarokin would support his conclusion that the "crime/fraud" exception applies.

Judge Sarokin's opinion in Haines precipitated a criminal investigation by the US Attorney's office in Brooklyn, New York ${ }^{14}$ to investigate whether or not there had been misrepresentation of the dangers of cigarette smoking in order to prop up cigarette sales, and hence industry profits. If there had been such misrepresentation, this would be known in common law as "larceny by trick", and would be grounds for prosecution by US Attorneys as "mail fraud" or "wire fraud", or as a violation of the Racketeer Influenced and Corrupt Organizations Act (RICO).

The Haines "special project" documents have yet to be shared with plaintiffs' attorneys, and the US Attorney's investigation has yet to be concluded. Meanwhile, the cigarette companies are seeking and obtaining injunctions to keep disaffected former employees from talking with the press or with plaintiff's attorneys. ${ }^{15}$ Perhaps the industry will succeed in bottling up these documents, investigations, and witnesses, as well as others like them. If it fails, however, it may lose what remains of its image as a group of reasonably ethical, lawabiding businessmen - an image which thus far has deflected the full anger of jurors, legislators, and the general public.

\section{"Public interest" actions}

The Australian Federation of Consumer Organizations (AFCO) pioneered the use of public interest actions in tobacco litigation. "Public interest" actions differ from most civil actions, and from criminal prosecutions, in that they are brought by private parties, but seek relief not for their private benefit but on behalf of the general public. Hence, the plaintiffs are sometimes referred to as "private attorneys general".

AFCO sued the Tobacco Institute of Australia (TIA) to establish the falsity of its claim that "there is little evidence and nothing which proves scientifically that cigarette smoke causes disease in non-smokers". 1 The impact in Australia of the judicial decision upholding AFCO's complaint was similar to the impact in the US of the release of the Environmental Protection Agency's (EPA) report on the health effects of ETS; both had the effect in their respective countries of ending the national "debate" on the dangers of ETS, and of accelerating the trends toward public and private smoking bans. ${ }^{16,17}$ In December 1992 
the AFCO decision was upheld on appeal. ${ }^{18}$

As public interest actions are not limited by the scope of the plaintiff's injuries, the judicial relief sought can be tailored directly to tobacco control goals. In Mangini $v$ Rf Reynolds Tobacco $C o,{ }^{19}$ the plaintiff claimed that Reynolds' "Old Joe Camel" marketing campaign targeted children and teenagers, and therefore constituted "unfair, deceptive, untrue, or misleading advertising" in violation of the California Business and Professions Code. ${ }^{20}$ The plaintiff, a domestic relations attorney, is not herself a member of the targeted class, but sues as a person acting for the interests of the general public.

The Mangini complaint seeks to require Reynolds to undertake a corrective advertising campaign in print media and on television stations in California to warn consumers of the health hazards of smoking, as well as to disgorge the profits it made from its alleged targeting of minors. The trial judge dismissed the case on the theory that it was pre-empted by the Federal Cigarette Labelling and Advertising Act, but an appellate court reinstated it, concluding that the US Supreme Court's reasoning in Cipollone, ${ }^{12}$ that fraud claims did not come within the pre-emptive ambit of the Act, applied equally to claims that cigarette advertising unfairly targeted minors. ${ }^{21}$ While the California Supreme Court is currently reviewing the pre-emption issue, if it finds for the plaintiff, courts in California (and elsewhere) will be able to review the fairness of the industry's behaviour toward children and other vulnerable groups, and to require powerful corrective measures for any unfairness they find. If this occurs, it will require radical changes in the industry's behaviour.

\section{Product liability suits}

Tobacco product liability suits seek compensation for the damages which the plaintiff has suffered, either directly through his/her own tobacco-caused disease, or indirectly as the result of such a disease suffered by a family member. Many legal theories have been urged in support of such suits, including fraud and conspiracy, negligence, breach of express or implied warranties, and strict liability.

Recovery for "strict liability" in product liability cases is generally permitted in the US where the product is shown to be "in a defective condition unreasonably dangerous to the user or consumer". Early tobacco liability cases foundered on the notion that a cigarette is not "dangerous to an extent beyond that which would be contemplated by the ordinary consumer who purchases it, with the ordinary knowledge common to the community as to its characteristics". ${ }^{22}$ More recent cases have rejected this reasoning, noting that "information has been widely disseminated only in recent years", that the tobacco industry has vigorously contradicted this information, that a smoker may have become addicted at a young age and years ago, and that therefore, "as a matter of public policy, the manufacturers of cigarettes should not be immunized from liability for harm caused by their products". ${ }^{23}$

In 1993 a Mississippi trial judge broke new ground by squarely confronting for the first time the implications of strict liability in cigarette cases. Judge Bogen concluded that:

"... cigarettes are, as a matter of law, defective and unreasonably dangerous for human consumption. Cigarettes are defective because when used as intended, they cause cancer, emphysema, heart disease and other illnesses. That the result reached here imposes absolute liability on the manufacturers of cigarettes for injuries arising from the use of their products is not a departure from the doctrine of strict liability, rather the logical extension of the doctrine in light of present day scientific and medical knowledge and the enormous economic burden which cigarettes place on the nation's economy and its health care system in particular."24

Judge Bogen also made short shrift of the cigarette companies' favourite defence - that the smoker was somehow at fault for using their products in the face of public knowledge of the dangers. He ruled that such a defence was available only where the consumer's conduct was "venturous", or where he misused or abnormally handled the product. $\mathrm{He}$ noted that "No such claim is made here. Plaintiffs' [father] did with Pall Mall cigarettes just what Defendants intended be done, he smoked them".

While Judge Bogen's reasoning has not yet been accepted, or rejected, by an appellate court, it would immediately establish the liability of cigarette manufacturers to all present and former customers who can show their diseases are causally attributable to the use of the manufacturers' products. ${ }^{25}$ If the courts of even a single state were to adopt this reasoning, many others would be likely to follow so as to provide their own citizens with the financial benefits of applying this straightforward legal reasoning to recover their cigarette-caused losses from cigarette manufacturers.

Almost as important as favourable legal theories in winning tobacco liability cases are procedures and judicial attitudes which prevent the cigarette companies from carrying out their strategy of "making that other son of a bitch (ie, the plaintiff's lawyer) spend all of his" money prosecuting the case. Thus, in 1992 the law firm that had brought Cipollone and some other cases sought to drop them on the basis that the tobacco industry's defensive tactics made the cases so expensive that the cost of bringing them exceeded the likely recovery. When one of their plaintiffs objected to being dropped, Judge Lechner (who replaced Judge Sarokin after he was disqualified) refused to excuse the law firm, on the basis that if judges do their job of interpreting the procedural rules "to secure the just, speedy, and inexpensive determination of every action," ${ }^{26}$ these cases could be tried without bankrupting either the plaintiffs or their law firms. ${ }^{27}$ Trial judges have broad discretion in deciding procedural questions, and a determination by trial judges not to permit pre-trial tactics that prevent tobacco plaintiffs from ever getting their "day in court" will en- 
courage many presently diffident plaintiffs' attorneys to attempt these cases.

One type of cigarette litigation which tobacco control advocates are particularly excited about involves asbestos-containing cigarette filters. In the 1950s, Lorillard, Inc, successfully touted the "Micronite filter" on its Kent cigarettes as eliminating more of the tar and nicotine from tobacco smoke than its competing brands. However, the filter contained crocidilite asbestos, and a number of former Kent smokers are now contracting mesothelioma, a rare cancer almost always linked to asbestos exposure. It would be a bitter irony if a smoker were to switch to a filter brand to protect his health, only to develop a fatal disease for which he would not otherwise have been at risk.

\section{Third-party victim suits}

In 1987 a Technical Study Group, which included representatives of the leading US cigarette companies, issued a report which found "that it is technically feasible and may be commercially feasible to develop cigarettes that will have a significantly reduced propensity to ignite upholstered furniture or mattresses". ${ }^{28}$

A strong case can be made that the industry is liable to the 3500 Americans who are seriously injured each year, and the families of the 1200 who die, from cigarette-caused fires. According to one study, one-third of these are innocent victims: children and adults who were trapped in a fire caused by someone else's dropped cigarette. ${ }^{29}$ The refusal of an entire industry to make the simple changes in its product described in the report - lowering the cigarette's circumference, tobacco density, paper porosity, and burn-enhancing additives - imposes a foreseeable, unnecessary and unreasonable risk upon its consumers and upon others who share housing with its consumers. This behaviour is grossly negligent, and perhaps reckless. ${ }^{30}$

In 1990 a Boston smoker fell asleep with his Marlboro Lights cigarette still lit; the resulting house fire killed a mother and her three young children. A case brought on behalf of the estates of these innocent victims is scheduled for trial in 1994 in Federal District Court. ${ }^{31} \mathrm{~A}$ successful result would doubtless lead to hundreds of similar cases, and widespread outrage at the callousness of an industry that continues to cause this needless carnage.

Of course, non-smokers also suffer a wide range of illnesses as a result of exposure to ETS. In addition to the class action on behalf of flight attendants, ${ }^{32}$ which was discussed in the earlier litigation review, ${ }^{1}$ two other ETS cases against the cigarette industry are currently pending. One, Butler $v$ RF Reynolds Tobacco $\mathrm{Co}^{33}$ involves a Mississippi nonsmoker who contracted lung cancer after years of cutting hair in a smoky barbershop; it is scheduled for trial late in 1994. The other, Dunn v RFR Nabisco Holdings Corp, ${ }^{34}$ involves a non-smoking Indiana nurse who contracted lung cancer after 17 years of working at a smoky Veterans Administration hospital. These cases are timely now that the EPA's report has heightened public awareness of the hazards of ETS; the "innocence" of the plaintiffs also seems clear. Since current estimates are that over 50000 Americans die each year from ETS exposure, ${ }^{35}$ success in any of these cases could easily open the floodgates.

\section{Cessation reimbursement claims}

Another appealing plaintiff is the smoker who wants the company or companies that hooked him on nicotine, and profited greatly from his years of addiction, to pay for his efforts to quit. Some issues that have loomed large in personal injury or wrongful death suits do not arise in these cases. Thus, while the jury in the Cipollone case puzzled over whether Rose Cipollone was really "addicted" (as the family's attorney claimed) or was just a headstrong hedonist (as the defence alleged), no one goes through smoking cessation procedures "for the fun of it", and smokers cannot obtain nicotine replacement devices if they have not been clinically diagnosed as nicotine-dependent. Similarly, while a plaintiff seeking six- or seven-figure damages can be denigrated as a "sore loser", a risk-taker whose luck ran out and now is seeking a windfall as consolation, an otherwise healthy smoker who tries to quit is admirable, a solid, risk-averse citizen trying his best to do what his American Cancer Society and Surgeon General ask of him, and making a modest claim for financial assistance for his efforts.

Cessation reimbursement claims also differ from personal injury claims in that they can be asserted either in small claims court, the simplest of legal proceedings, or in complex class actions. Since the typical claim seeks only the cost of medical diagnosis, nicotine replacement therapy, and associated counselling... perhaps $\$ 1000$ in all, it comes within the jurisdictional limits of small claims courts. As a practical matter, this means the case can (and sometimes must) be asserted by the plaintiff himself, without the active participation of a lawyer; defendants are sometimes precluded from bringing a lawyer as well. This does not, of course, guarantee a plaintiff's verdict; indeed, the only such case tried thus far went for the cigarette company, on the ground that the plaintiff's statute of limitations had expired. ${ }^{36}$ Such cases are very inexpensive to bring, and each one has the potential to be the industry's first loss, with the accompanying front-page headlines and widespread emulation.

The small size of the individual claims also makes them amenable to class action treatment. The plaintiffs are similarly situated, since they all suffer from the same medical condition (nicotine dependence) and are all seeking similar types and amounts of recovery. Since consumers currently spend an aggregate of over $\$ 1$ billion annually in diagnosis, nicotine replacement therapy, and related counselling, there should be enough at stake to attract the most highly skilled attorneys. 
Reimbursement of third-party payers

Most medical costs are paid, not by the patient or their family, but by governments or private insurers. In the US, third-party payers have a "subrogation" right to recover their payments from any entity which would have been liable to the patient had he/she paid their own costs. Although the third-party payer which brought such an action against a cigarette company would be subject to whatever defences the company would have had against the smoker, the judge or jury might be less inclined to "blame the victim" where their punishment would fall not on the smoker or their family but on the general public (through taxes or insurance premiums).

Furthermore, uncompensated third-party payers, such as public hospitals and Medicaid programmes, could be seen as direct foreseeable victims of the tobacco industry's irresponsible behaviour and unreasonably dangerous products. Just as the cigarette companies can anticipate and calculate, for every thousand customers, the amount of tobaccorelated expenses, disease, and death these customers will suffer, so can they anticipate and calculate the amount of uncompensated medical care that will be required. As financially injured parties suing in their own right, uncompensated payers would not be subject to defences based on the smokers' conduct. Each payer might also be able to aggregate tobaccorelated medical expenses, and recover from each cigarette company in proportion to its market share.

Third-party payer recoveries could be facilitated by state statutes, which could simplify procedures for aggregating expenses and apportioning liability. ${ }^{37}$ Once one state adopts such a statute, others are likely to follow, since it might be difficult for politicians in any state to explain to their constituents why they are paying higher taxes or health insurance premiums than citizens of a neighbouring state. The amounts of money involved in reimbursing third-party payers in any one state would be very substantial; if the practice spread, the amounts could become, from the industry's perspective, catastrophic.

\section{Conclusion}

Discussing the catastrophic possibilities of various types of tobacco litigation may have the paradoxical effect of frightening judges into twisting doctrines so as to frustrate these possibilities. Indeed, these very fears may help explain why five US Court of Appeals ${ }^{38}$ from 1986 to 1989 adopted far-reaching and legally insupportable interpretations of the preemptive effect of the Federal Cigarette Labelling and Advertising Act, while a friend-ofthe-court brief supporting the plaintiff, ${ }^{39}$ by citing the paucity of new cases following the favourable Cipollone verdict in 1988, reassured the US Supreme Court, which overruled the Courts of Appeals in 1992. ${ }^{12}$

The prospect of a catastrophe for the tobacco industry should not frighten responsible public authorities, since it would also be a triumph for public health. ${ }^{40}$ It also need not be a catastrophe for the judicial system, since existing legal institutions such as bankruptcy and class actions, as well as additional legal mechanisms which Congress could create (perhaps modeled on workers compensation laws), have shown themselves capable of handling massive numbers of individual claims. The worst catastrophe would be if the magnitude of the injuries which the tobacco industry has inflicted is used as an excuse to refuse redress to the victims, and to encourage the industry to continue to inflict injury.

1 Daynard RA, Recent developments in tobacco litigation 1991. Tobacco Control 1992; 1: 37-45.

2 Spencer L. Just smoke, Forbes, December 23, 1991: 41.

3 Scholem $v$ Department of Health, District Ct, NSW. \#40830/86; the jury charge appears at Tobacco Products Litigation Reporter 1992; 7 (3): $3.87-3.115$

4 Imamura v City \& County of Honolulu \#29208149, 8 TPLR 8.1 (Haw. Disability Comp. Div. 1993). For other cases see Sweda EL, Summary of legal cases regarding smoking in the workplace and other places. Tobacco Products Litigation Reporter 1993; 8 (4): 4.11.

5 Pertschuk $M$. Tobacco industry strategies and tactics Presentation at the Seventh National Conference on Chronic Disease Prevention and Control, sponsored by the US Centers for Disease Control, 21-23 October 1992 Salt Lake City, Utah.

6 Time, June 27, 1988: 48

7 Cited and quoted in Haines $v$ Liggett Group, Inc 8.1 Tobacco Products Litigation Reporter 2.1, 814 F.Supp. 414 (DNJ 1993).

8 Zeeman EC. Catastrophe theory. Sci Am 1976; 234: 65-83.

9 Brodeur P. Outrageous misconduct New York: Pantheon, 1985

10 Hersch J, Tobacco: peering through the smokescreen. $M f$ Whitman Investment Research 1993.

11 Levin S, Products liability lawsuits against cigarette manufacturers - the first wave. Tobacco Products Litigation Reporter 1985; 1 (1): 4.1-4.11.

12 7.2 Tobacco Products Litigation Reporter 2.29, 2.45, 112 Supreme Ct 2608 (1992). See Daynard RA, US Supreme Court opens new areas for litigation and regulation. Tobacco Control 1992; 1 : 165-6.

13 7.1 Tobacco Products Litigation Reporter 2.1, 140 F.R.D. 681 (DNJ 1992), reversed and remanded 7.4 Tobacco Products Litigation Reporter 2.102, 975 F. 2d 81 (3d Cir. 1992).

14 Is the Tobacco Industry a "Racketeer Influenced and Corrupt Organization"? Tobacco on Trial 1992, April

15 See RJ Reynolds Tobacco Co $v$ Colucci, 8.2 Tobacco Products Litigation Reporter 2.225 (NC Superior Ct 1993); Maddox $v$ Williams, No. 93CI04806, Jefferson City Cir. Ct, Ky.

16 Negri G. Australian court ruling called impetus for mass antismoking lobby. Boston Globe 1991; July 25:20

17 Complaint for declaratory and injunctive relief, Flue-Cured Tobacco Cooperative Stabilization Corp $v$ US Environmental Protection Agency, US Dist Ct, M.D. North Carolina. Tobacco Products Litigation Reporter 1993; (2): 3.97-3.112.

18 Tobacco Institute of Australia $v$ Australian Fed. of Consumer Organizations, \#G217 of 1991, 8.1 Tobacco Products Litigation Reporter 2.24 (Fed Ct NSW Div 1993).

19 San Francisco Superior Ct, \#939359; the complaint appears in Tobacco Products Litigation Reporter 1992; 7 (1): $3.24-3.28$

20 Bus. and Prof. Code sec. 17200.

21 Mangini $v$ RJ Reynolds Tobacco Co, 8.3 Tobacco Products Litigation Reporter 2.239 (Cal. Ct App. 1993).

22 Roysdon $v$ RJ Reynolds Tobacco Co, 1.2 Tobacco Products Litigation Reporter 2.47, 623 F. Supp. 1189 (D. Tenn 1985) (quoting Restatement 2d of Torts, sec. 402A, comment i), affirmed, 3.6 Tobacco Products Litigation Reporter 2.138, 849 F. 2d 230 (6th Cir. 1988).

23 Dewey $v$ RJ Reynolds Tobacco Co, 5.3 Tobacco Products Litigation Reporter 2.65, 121 NJ 69, 577 A. 2d 1239 (NJ Superior $\mathrm{Ct}, 1990)$; Gilboy $v$ American Tobacco Co., 6.2 Tobacco Products Litigation Reporter 2.295, 582 So. $2 \mathrm{~d}$ 1263 (La. S. Ct, 1991).

24 Wilks $v$ American Tobacco Co, \#91-12,355 (B) (W), 8.2 Tobacco Products Litigation Reporter 2.209 (Washington Cty Cir. Ct, Miss. 1993)

25 Ironically, in the Wilks case itself the jury concluded that the smokers' death was caused not by his cigarette-related emphysema or lung cancer, but as a result of a blood clot induced by a urinary tract infection. Tobacco Products Litigation Reporter 1993; 8 (2): 1.16

26 Federal Rules of Civil Procedure, Rule 1

27 Haines $v$ Liggett Group, Inc 8.1 Tobacco Products Litigation Reporter 2.1, 814 F.Supp. 414 (DNJ 1993)

28 Technical Study Group. Toward a less fire-prone cigarette: 
Final report of the technical study group on cigarette and little cigar fire safety; Oct. 1987 at 1 . Copies of this report can be obtained from the Consumer Product Safety Commission, 5401 Westbard Avenue, Washington, DC 20207, USA.

29 Mierley MC Baker SP Fatal house fires in an urban population. $\mathcal{F} A M A$ 1983; 249: 1466-8.

30 McGuire A, Daynard RA. Product liability suits for tobacco-industry-caused fires. Trial 1992;28 (Nov): tis

31 Kearney $v$ Philip Morris Companies, Inc, No. 92-11079K (US District Ct, Mass). The complaint, filed May 11, 1992, appears in Tobacco Products Litigation Reporter $1992 ; 7$ (2): $3.65-3.68$

32 Broin $v$ Philip Morris Companies, Inc, No 91-49738, 11th Cir Ct, Dade Cty, Fa. The trial judge ruled in 1992 that the case could not proceed as a class action, 7.2 Tobacco Products Litigation Reporter 264; his ruling is presently on appeal.

33 No J92-0732 (B) (W), Cir Ct, Hinds City, Miss. The complaint appears in Tobacco Products Litigation Reporter $1993 ; 8(1): 3.1-3.4$
34 No 18DO1-9305-CT-06, Superior Ct, Delaware Cty, Ind The complaint appears in Tobacco Products Litigation Reporter 1993; 8 $(2): 3.132-3.135$.

35 Glantz SA, Parmley WW. Passive smoking and heart disease: epidemiology, physiology, and biochemistry.

36 Small Claim Founders of Statute of Limitations. Tobacco Products Litigation Reporter 1993; 8 (2): 1.17

$37 \mathrm{Eg}$, Commonwealth of Massachusetts, House Bill No. 5099 (1993), reprinted in Tobacco Products Litigation Reporter $1993 ; 8$ (2): 7.12 .

38 Cipollone $v$ Liggett Group, Inc, 789 F.2d 181 (3d Cir 1986); Stephen $v$ American Brands, Inc, $825 \mathrm{~F} 2 \mathrm{~d} 312$ (11th Cir 1987); Palmer v Liggett Group, Inc, $825 \mathrm{~F} 2 \mathrm{~d}$ 620 (1st Cir 1987); Roysdon U RJ Reynolds Tobaco Co, 849 F.2d 230 (6th Cir 1988); Pennington $v$ Vistron Corp, 876 F. 2d 414 (5th Cir 1989). PC in Support of Petitioner, reprinted in Tobacco PC in Support of Petitioner, reprinted in Tobacco

40 Daynard RA. Tobacco liability litigation as a cancer control strategy. $\mathcal{F}$ Natl Cancer Inst 1988; 80: 9-13.
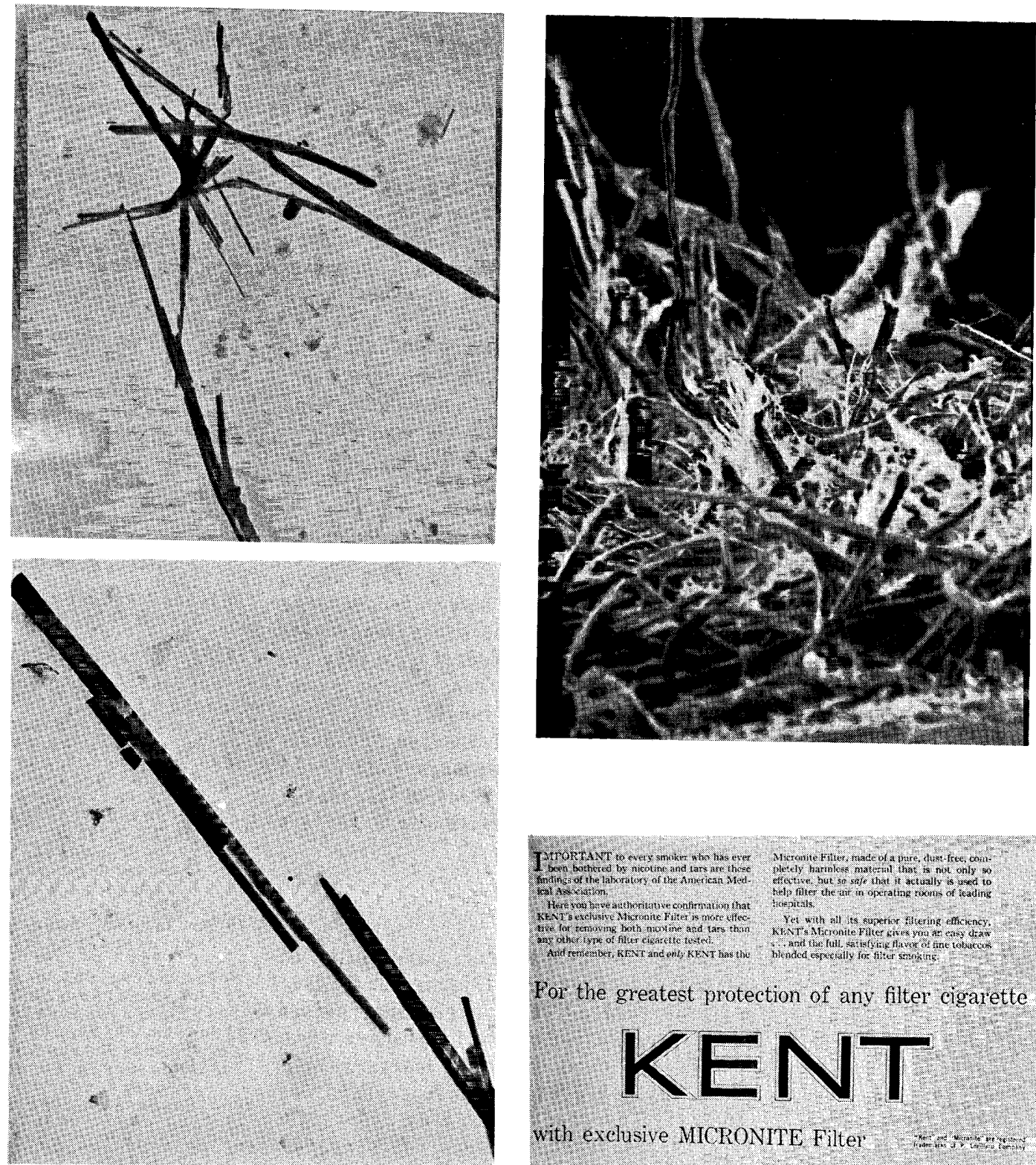

Several lawsuits have been filed against Lorillard by individuals who smoked Kent cigarettes with the original Micronite filter and who have developed mesothelioma, a rare cancer strongly linked to asbestos exposure. The figure in the upper left is a transmission electron micrograph (TEM) taken in 1954 by Ernest Fullam, showing crocidolite (blue) asbestos fibres in smoke from a Kent cigarette with the Micronite filter. In the upper right is a 1990 TEM by William Longo of Materials Analytic Services (Atlanta, Georgia), also showing crocidolite asbestos fibres in smoke from a Kent cigarette with the original Micronite filter. In the lower left is a scanning electron micrograph by Longo showing the proximal end of an original Micronite filter; interspersed among the matrix of large fibres are dense white needles of crocidolite asbestos. The advertisement for Kent shown in the lower right is from Life Magazine, 1954 ; it states that the Micronite filter is "made of a pure, dust-free, completely harmless material that is ... so safe that it actually is used to help filter the air in operating rooms of leading hospitals". Source: fohn Slade. 